\title{
Pengaruh Model Inkuiri Terbimbing Berbantuan Media Audio Visual Terhadap Kemampuan Pemahaman Konsep Siswa SD
}

\author{
Hayatun Nupus ${ }^{1}$, Molli Wahyuni ${ }^{2}$, Lusi Marleni ${ }^{3 *}$ \\ ${ }^{123}$ (PGSD, Universitas Pahlawan Tuanku Tambusai, Riau) \\ * Hayatun Nupus. E-mail: ${ }^{1}$ nupus.hn105@gmail.com
}

\begin{abstract}
Abstrak. Penelitian ini bertujuan untuk mengetahui pengaruh model inkuiri terbimbing berbantuan media audio visual terhadap kemampuan pemahaman konsep siswa sekolah dasar. Jenis penelitian yang digunakan adalah penelitian kuasi eksperimen dengan desain non equivalent control group design. Populasi dalam penelitian ini adalah seluruh siswa kelas IV SDN 001 Air Tiris dengan sampel kelas IVB sebagai kelas kontrol dan kelas IVC sebagai kelas eksperimen yang diambil menggunakan teknik purposive sampling. Instrumen penelitian yang digunakan berupa tes, observasi dan dokumentasi. Hasil analisis data diperoleh bahwa rata-rata kemampuan pemahaman konsep menggunakan model inkuiri terbimbing berbantuan media audio visual lebih tinggi $(86,16)$ daripada menggunakan model konvensional $(76,79)$. Hal tersebut dibuktikan dari hasil uji-t dengan taraf signifikansi $5 \%$ diperoleh nilai sig $(2$-tailed $)(0,002)<\alpha(0,05)$ sehingga $\mathrm{H}_{\mathrm{a}}$ diterima dan $\mathrm{H}_{\mathrm{o}}$ ditolak. Maka dapat disimpulkan bahwa model inkuiri terbimbing berbantuan media audio visual berpengaruh terhadap kemampuan pemahaman konsep siswa.
\end{abstract}

Kata Kunci: Model Inkuiri Terbimbing, Media Audio Visual, Kemampuan Pemahaman Konsep

Abstract. This study aims to determine the effect of a guided inquiry model assisted by audiovisual media on the ability to understand concepts of elementary school students. The type of research used is a quasi-experimental study with a non-equivalent control group design. The population in this study were all IV grade students of SDN 001 Air Tiris with a sample of class IVB as the control class and class IVC as the experimental class which were taken using purposive sampling technique. The research instrument used in the form of tests, observations and documentation. The results of data analysis showed that the average ability to understand concepts using the guided inquiry model assisted by audio-visual media was higher (86.16) than using the conventional model (76.79). This is evidenced from the results of the t-test with a significance level of 5\% was obtained sig (2-tailed) (0.002) $<\alpha(0.05)$ so that $H_{a}$ is accepted and $H_{o}$ is rejected. So it can be concluded that the guided inquiry model assisted by audio-visual media has an effect on students' conceptual understanding abilities.

Keywords: Guided Inquiry Model, Audio Visual Media, Concept Understanding Ability

\section{Pendahuluan}

Kurikulum 2013 (K-13) di sekolah dasar menekankan pada pembelajaran tematik. Pembelajaran tematik merupakan pembelajaran terpadu yang menggunakan tema untuk mengusung beberapa mata pelajaran sehingga memberikan pengalaman yang bermakna pada anak 
(Permendikbud, 2013). Dalam proses pembelajaran dipayungi oleh sebuah tema yang mengaitkan beberapa mata pelajaran sehingga pemisahan antar mata pelajaran tidak terlalu jelas terlihat. Pada pembelajaran tematik memuat beberapa mata pelajaran, salah satunya Ilmu Pengetahuan Alam (IPA).

Ilmu Pengetahuan Alam (IPA) merupakan mata pelajaran yang membahas tentang gejala-gejala alam yang disusun secara sistematis yang didasarkan pada hasil percobaan dan pengamatan yang dilakukan oleh manusia (Samatowa, 2011). Sujana (dalam Abdillah \& Anggara, 2021) juga mengatakan bahwa IPA merupakan ilmu yang mempelajari fakta, konsep atau prinsip dan membutuhkan ketrampilan proses sains dalam mempelajarinya.

Salah satu produk ilmiah yang dimaksud dalam pembelajaran IPA adalah kemampuan pemahaman konsep. Sutrisno (dalam Ningsih, 2019) mengatakan bahwa seseorang dikatakan memahami akan sesuatu ketika mereka dapat memaparkannya dengan rinci dan menjelaskannya. Sedangkan konsep menurut Hamzah (dalam Chalilati, 2019) menjelaskan bahwa gambaran suatu objek ataupun persitiwa yang terjadi yang dirumuskan dengan kata-kata.

Anderson et al. (dalam Abdillah \& Anggara, 2021) mengatakan bahwa pemahaman konsep merupakan kegiatan menyatakan ulang, memberi contoh, dan mengaitkan berbagai konsep yang telah dipelajari. Jadi kemampuan pemahaman konsep adalah kemampuan siswa untuk dapat memahami suatu konsep atau fakta dan menjawabnya dengan menggunakan kalimat sendiri tanpa mengubah arti dari konsep yang dimaksudkan.

Pembelajaran IPA di sekolah dasar hendaknya menjadi sarana bagi siswa untuk memahami diri sendiri dan lingkungannya serta prospek pengembangan lebih lanjut penerapan IPA dalam kehidupan sehari-hari (BSNP, 2006). Mengingat pentingnya pemahaman konsep dalam pembelajaran IPA, maka kemampuan siswa dalam memahami konsep ilmiah perlu lebih ditingkatkan lagi, karena nilai pemahaman konsep berarti siswa tidak sebatas memahami konsep, tetapi juga dapat menjelaskan materi yang telah dipelajarinya dalam kalimat mereka sendiri dan dapat diterapkan dalam kehidupan sehari-hari.

Berdasarkan observasi awal dan wawancara pada tanggal 8 maret 2021 yang dilakukan peneliti dikelas IV SDN 001 Air Tiris diketahui bahwa penerapan kemampuan pemahaman konsep dalam pembelajaran IPA belum terlaksana dengan maksimal. Guru masih cenderung menggunakan metode ceramah daripada memberikan kesempatan kepada siswa untuk menemukan sendiri konsep-konsep yang dipelajarinya. Sehingga siswa merasa materi IPA hanya sebatas hafalan saja dan tidak bermakna. Faktor lain yang mempengaruhi rendahnya kemampuan pemahman konsep siswa antara lain siswa tidak dapat menjelaskan kembali materi yang dipelajari serta siswa belum mampu menyimpulkan materi yang dipelajari dengan kalimatnya sendiri. Hal ini akan berdampak pada tingkat pemahaman konsep siswa.

Rendahnya pemahaman konsep siswa diperkuat dengan data perolehan yang ada dilapangan belum memenuhi harapan. Dari data perolehan nilai Penilaian Tengah Semester siswa kelas IV semester 2 pada mata pelajaran IPA tahun 2020/2021, sebagian nilai siswa masih di bawah KKM (Kriteria Ketuntasan Minimal=75) yang ditetapkan oleh sekolah Dari tiga kelas responden diperoleh data bahwa terdapat $42,9 \%$ - 61,9\% nilai siswa yang masih berada di bawah KKM. Rendahnya nilai siswa disebabkan kurangnya kemampuan siswa dalam memahami konsep materi pelajaran khususnya IPA. Kemampuan pemahaman konsep siswa akan meningkat jika dalam proses pembelajaran IPA menggunakan model pembelajaran yang tepat. Model pembelajaran yang dapat diterapkan dalam pembelajaran IPA adalah model inkuiri terbimbing. 
Model inkuiri terbimbing merupakan kegiatan pembelajaran yang melibatkan secara maksimal seluruh kemampuan siswa untuk mencari dan menyelidiki sesuatu (benda, manusia atau peristiwa) secara sistematis, kritis, logis, analitis sehingga mereka dapat merumuskan sendiri penemuannya dengan penuh percaya diri. Jauhar (dalam Budiasa \& Ketut Gading, 2020) mengatakan model pembelajaran inkuiri terbimbing merupakan model pembelajaran yang memungkinkan guru untuk membimbing siswa dalam pemecahan masalah dengan mengajukan pertanyaan awal dan mengarahkan siswa dalam diskusi.

Model inkuiri terbimbing hendaknya bermanfaat bagi siswa dalam proses pembelajaran. Model inkuiri terbimbing tidak hanya memungkinkan siswa untuk mencatat dan mengingat materi yang diperoleh, tetapi juga menuntut siswa untuk membangun pengetahuannya sendiri. Hal di atas diperkuat oleh penelitian yang dilakukan oleh Koten et al (2019) menunjukkan hasil penelitian bahwa ratarata skor pemahaman konsep di kelas eksperimen $(83,83)$ lebih tinggi dibandingkan kelas kontrol $(72,50)$. Dapat disimpulkan penggunaan model inkuiri terbimbing memiliki pengaruh terhadap kemampuan pemahaman konsep IPA.

Untuk dapat mendukung terwujudnya penerapan suatu model pembelajaran, guru dapat menggunakan berbagai macam media pembelajaran yang dapat mendukung proses pembelajaran IPA. Salah satunya adalah dengan menggunakan media audio visual. Media audio visual merupakan gabungan dari media visual dan audiotori. Video merupakan salah satu media audio visual yang dapat digunakan sebagai media pembelajaran untuk berbagai mata pelajaran (Arsyad, 2016).

Penggunaan media audio visual dalam model inkuiri terbimbing diharapkan dapat meningkatkan pengaruhnya dan memaksimalkan tujuan pembelajaran. Selain melakukan eksperimen ilmiah, siswa juga menggunakan media audio visual untuk memahami konsep materi, contoh atau peristiwa yang tidak dapat dilakukan melalui peristiwa eksperimen nyata (Magfirah et al., 2019). Maduretno et al (dalam Magfirah et al., 2019) mengatakan penggunaan media audio visual pada model inkuiri terbimbing membuat siswa lebih percaya pada kemampuan diri sendiri dengan kemampuannya berfikir, mencari informasi dan belajar dari sumber lain.

Media audio visual digunakan pada model inkuiri terbimbing karena menyesuaikan karakteristik materi yang memerlukan penjelasan yang lebih spesifik untuk membantu siswa memahami konsep yang disajikan. Nugraha et al (dalam Magfirah et al., 2019) menjelaskan, pembelajaran melalui pemanfaatan video sebagai media pembelajaran dapat memberikan dampak positif, seperti meningkatkan pemahaman dan penguasaan konsep siswa. Pembelajaran akan lebih bermakna ketika siswa dapat mendengarkan dan melihat secara langsung proses pembelajaran dengan memanfaatkan media audio visual seperti film dan video (Ananda, 2017).

Berdasarkan latar belakang yang telah dipaparkan di atas, maka pentingnya dilaksanakan penelitian lebih lanjut yang berjudul "Pengaruh Model Inkuiri Terbimbing Berbantuan Media Audio Visual Terhadap Kemampuan Pemahaman Konsep Siswa Kelas IV SDN 001 Air Tiris".

\section{Metode Penelitian Jenis Penelitian}

Penelitian ini menggunakan metode kuasi eksperimen dengan design nonequivalent control group design. Dalam desain ini, dua kelompok atau dua kelas akan mendapatkan perlakuan yang berbeda. Sugiyono (2019) menyatakan bahwa desain ini hampir sama dengan desain pretest dan posttest control group design, namun dalam penelitian ini kelompok eksperimen dan kelompok kontrol tidak dipilih secara acak. Adapun desain penelitiannya sebagai berikut: 
Jurnal Edumaspul, 5 (2), Year 2021 - 346

(Hayatun Nupus, Molli Wahyuni, Lusi Marleni)

eksperimen (IVC) lebih rendah dibanding kelas kontrol (IVB).

Tabel 1. Desain Penelitian

\begin{tabular}{c|c|c|c}
\hline Kelas & $\begin{array}{c}\text { Pretes } \\
\boldsymbol{t}\end{array}$ & $\begin{array}{c}\text { Perlakua } \\
\text { n }\end{array}$ & $\begin{array}{c}\text { Posttes } \\
\boldsymbol{t}\end{array}$ \\
\hline $\begin{array}{c}\text { Eksperime } \\
\mathrm{n}\end{array}$ & $\mathrm{O}_{1}$ & $\mathrm{X}$ & $\mathrm{O}_{2}$ \\
\hline Kontrol & $\mathrm{O}_{3}$ & - & $\mathrm{O}_{4}$ \\
\hline
\end{tabular}

Sumber: (Sugiyono, 2019)

Sebelum diberi perlakuan baik kelompok eksperimen $\left(\mathrm{O}_{1}\right)$ dan kelompok kontrol $\left(\mathrm{O}_{3}\right)$ diberi test yaitu pretest, dengan tujuan untuk mengetahui keadaan kelompok sebelum perlakuan. Kemudian kelompok eksperimen diberikan perlakuan menggunakan model inkuiri terbimbing berbantuan media audio visual (X) dan selanjutnya kelompok eksperimen $\left(\mathrm{O}_{2}\right)$ dan kelompok kontrol $\left(\mathrm{O}_{4}\right)$ diberikan test yaitu posttest, untuk mengetahui keadaan kelompok setelah perlakuan.

\section{Lokasi dan Waktu Penelitian}

Penelitian ini dilaksanakan di SDN 001 Air Tiris, yang beralamat di Kelurahan Air Tiris Kecamatan Kampar Kabupaten Kampar Provinsi Riau. Penelitian ini dilaksanakan pada semester ganjil tahun pelajaran 2021/2022, yang dilaksanakan pada bulan Juli sampai dengan Agustus 2021.

\section{Populasi dan Sampel}

Populasi dalam penelitian ini adalah seluruh siswa kelas IV SDN 001 Air Tiris yang berjumlah 63 siswa. Sedangkan sampel berjumlah 42 siswa yang terdiri dari dua kelas yaitu kelas IVB sebagai kelas kontrol berjumlah 21 siswa dan Kelas IVC sebagai kelas eskperimen berjumlah 21 siswa. Penentuan sampel menggunakan teknik purposive sampling yaitu dengan memberikan pertimbangan tertentu (Sugiyono, 2019). Maka berdasarkan usulan guru kelas dan kepala sekolah dipilih kelas IVC sebagai kelas eksperimen dan kelas IVB sebagai kelas kontrol dengan alasan nilai rata-rata siswa kelas

\section{Instrumen Penelitian}

Instrumen yang digunakan yaitu lembar observasi dan lembar tes. Lembar observasi digunakan untuk mengamati aktivitas guru dan siswa baik kelas kontrol maupun kelas eksperimen, sedangkan lembar tes digunakan untuk mengukur kemampuan pemahaman konsep siswa pada kelas kontrol maupun eksperimen. Sebelum lembar tes diberikan, maka terlebih dahulu dilakukan uji validitas, uji reliabilitas, uji daya pembeda dan uji tingkat kesukaran soal menggunakan bantuan program SPSS 22.0. Instrumen tes kemampuan pemahaman konsep terlebih dahulu di ujicobakan ke SD yang memiliki kelas yang sama dengan kondisi kelas tempat penelitian. Instrumen tes berupa 10 soal essay yang diujikan kepada 20 siswa.

Instrumen tes yang telah memenuhi kriteria valid, reliabel, memperoleh kriteria dalam tingkat kesukaran sedang dan memeiliki daya pembeda selanjutnya dapat digunakan dalam pelaksanaan tes kemampuan pemahaman konsep siswa pada kelas kontrom maupun kela eksperimen.

\section{Teknik Pengumpulan}

Data penelitian dikumpulkan melalui lembar observasi, lembar tes dan dokumentasi. Lembar observasi digunakan untuk untuk memperoleh kegiatan siswa dan guru baik kelas kontrol maupun eksperimen. Lembar tes digunakan untuk mengukur kemampuan pemahaman konsep siswa. Sedangkan dokumentasi digunakan untuk memperoleh keterangan ataupun informasi berupa foto dan video selama penelitian.

Adapun persentase kategori observasi aktivitas guru dan siswa disajikan dalam tabel berikut:

Tabel 2. Kategori Aktivitas Siswa dan Guru

\begin{tabular}{c|c}
\hline Interval & Kategori \\
\hline $76 \%-100 \%$ & Baik \\
\hline $56 \%-75 \%$ & Cukup \\
\hline
\end{tabular}


Jurnal Edumaspul, 5 (2), Year 2021 - 347

(Hayatun Nupus, Molli Wahyuni, Lusi Marleni)

\begin{tabular}{c|c}
\hline $40 \%-55 \%$ & Kurang \\
\hline$<40 \%$ & Tidak Baik \\
\hline
\end{tabular}

Sumber: Riduwan (dalam Zani, 2018)

Adapun kategori penilaian kemampuan pemahaman konsep disajikan dalam tabel berikut:

Tabel 3. Kategori Penilaian Kemampuan Pemahaman Konsep

\begin{tabular}{c|c}
\hline Nilai & Kategori \\
\hline $90-100$ & Sangat Tinggi \\
\hline $80-89$ & Tinggi \\
\hline $65-79$ & Sedang \\
\hline $55-64$ & Rendah \\
\hline $0-54$ & Sangat Rendah \\
\hline
\end{tabular}

Sumber: (Siregar, 2019)

\section{Teknik Analisis Data}

Teknik yang digunakan dalam analisis data untuk melihat bagaimana pengaruh model inkuiri terbimbing berbantuan media audio visual terhadap kemampuan pemahaman konsep siswa dibandingkan dengan menggunakan model konvesnional. Data yang di analisis adalah data kemampuan pemahaman konsep pretest (keadaan awal) dan nilai posttest (keadaan akhir) setelah perlakuan. Analisis data yang digunakan dalam penelitian ini dengan bantuan program SPSS 22.0. Uji normalitas menggunakan teknik kolmogorov smirnov. Uji homogenitas menggunakan teknik one way anova. Sedangkan uji hipotesis menggunakan uji $\mathrm{T}$ atau independent samples $t$ test.

\section{Hasil dan Pembahasan Hasil}

Berdasarkan hasil penelitian diperoleh data hasil pretest dan posttest pada kelas eksperimen dan kelas kontrol. Hasil perhitungan data skor pretest dan posttest dengan menggunakan program microsoft excel siswa kelas eksperimen dan kelas kontrol dapat dilihat pada tabel berikut ini:

Tabel 4. Deskripsi Data Pretest dan Posttest

\begin{tabular}{c|c|c|c|c}
\hline \multirow{3}{*}{ Data } & \multicolumn{2}{|c|}{ Data Pretest } & \multicolumn{2}{c}{ Data Posttest } \\
\cline { 2 - 5 } & Pre & Pre & Post & Post \\
& Eks & Kon & Eks & Kon \\
\hline
\end{tabular}

\begin{tabular}{l|c|c|c|c}
\hline $\mathrm{N}$ & 21 & 21 & 21 & 21 \\
\hline Max & 62,50 & 68,75 & 96,88 & 90,63 \\
\hline Min & 40,63 & 37,50 & 68,75 & 53,13 \\
\hline Mean & 53,72 & 55,21 & 86,16 & 76,79 \\
\hline Median & 53,15 & 53,15 & 87,50 & 78,13 \\
\hline Std & 5,730 & 7,864 & 8,243 & 9,661 \\
Dev & \multicolumn{4}{|c}{ Berdasarkan tabel 4. dapat }
\end{tabular}

disimpulkan bahwa rata-rata pretest kemampuan pemahaman konsep kelas eksperimen yaitu 53,72 sedangkan kelas kontrol yaitu 55,21. Rata-rata posttest kemampuan pemahaman konsep kelas eksperimen yaitu 86,16 sedangkan kelas kontrol 76,76. Dapat disimpulkan rata-rata kemampuan pemahaman konsep kedua kelas mengalami peningkatan, namun peningkatan pada kelas eksperimen lebih signifikan dibandingkan kelas kontrol.

Hasil rata-rata observasi keterlaksanaan proses pembelajaran terhadap aktivitas siswa dan guru yang dilakukan selama tiga kali perlakuan dapat dilihat pada tabel 5 berikut:

Tabel 5. Hasil Observasi Guru dan Siswa

\begin{tabular}{|c|c|c|c|c|}
\hline \multirow[t]{2}{*}{ Kelas } & \multirow[t]{2}{*}{$\begin{array}{l}\text { Obse } \\
\text { rvas }\end{array}$} & $\begin{array}{c}\text { Perlak } \\
\text { uan } \\
1\end{array}$ & $\begin{array}{c}\text { Perlak } \\
\text { uan } \\
2\end{array}$ & $\begin{array}{c}\text { Perlak } \\
\text { uan } \\
\mathbf{3}\end{array}$ \\
\hline & & $\%$ & $\%$ & $\%$ \\
\hline \multirow{2}{*}{$\begin{array}{l}\text { Eksper } \\
\text { imen }\end{array}$} & Guru & $88,9 \%$ & $94,4 \%$ & $100 \%$ \\
\hline & Sisw & $72,2 \%$ & $83,3 \%$ & $88,9 \%$ \\
\hline \multirow{2}{*}{$\begin{array}{l}\text { Kontro } \\
1\end{array}$} & Guru & $83,3 \%$ & $88,9 \%$ & $100 \%$ \\
\hline & Siswa & $77,8 \%$ & $77,8 \%$ & $83,3 \%$ \\
\hline
\end{tabular}

disimpulkan bahwa rata-rata aktivitas siswa cenderung meningkat secara signifikan pada kelas eksperimen daripada kelas kontrol. Hal ini dapat dilihat pada persentase aktivitas siswa kelas kontrol selalu menunjukkan adanya peningkatan, namun peningkatannya tidak sesignifikan seperti pada kelas eksperimen. Hal ini berarti rata-rata aktivitas pada kelas eksperimen lebih efektif daripada kelas kontrol.

\section{Analisis Data}

1. Uji Normalitas

Tabel 6. Hasil Uji Normalitas 
Jurnal Edumaspul, 5 (2), Year 2021 - 348

(Hayatun Nupus, Molli Wahyuni, Lusi Marleni)

\begin{tabular}{c|c|c|c}
\hline \multirow{2}{*}{ Data } & \multicolumn{2}{|c|}{$\begin{array}{c}\text { Kolmogorov } \\
\text { Smirnov }\end{array}$} & \multirow{2}{*}{ Keterangan } \\
\cline { 2 - 3 } & $\mathbf{N}$ & Sig. & \\
\hline $\begin{array}{c}\text { Pre } \\
\text { Eks }\end{array}$ & 21 & 0,108 & $\begin{array}{c}\text { Berdistribusi } \\
\text { normal }\end{array}$ \\
\hline $\begin{array}{c}\text { Pre } \\
\text { Kon }\end{array}$ & 21 & 0,200 & $\begin{array}{c}\text { Berdistribusi } \\
\text { normal }\end{array}$ \\
\hline $\begin{array}{c}\text { Post } \\
\text { Eks }\end{array}$ & 21 & 0,063 & $\begin{array}{c}\text { Berdistribusi } \\
\text { normal }\end{array}$ \\
\hline $\begin{array}{c}\text { Post } \\
\text { Kon }\end{array}$ & 21 & 0,200 & $\begin{array}{c}\text { Berdistribusi } \\
\text { normal }\end{array}$ \\
\hline
\end{tabular}

Berdasarkan tabel 6 dapat diketahui bahwa hasil uji normalitas data pretest kelas eksperimen diperoleh nilai sig $=0,108$ $>0,05$, kelas kontrol diperoleh nilai sig $=$ $0,200>0,05$. Sedangkan hasil uji normalitas data posttest kelas eksperimen diperoleh nilai sig $=0,063>0,05$, kelas kontrol diperoleh nilai sig $=0,200>0,05$. Dapat disimpulkan bahwa keempat data tersebut berdistribusi normal.

\section{Uji Homogenitas}

Tabel 7. Hasil Uji Homogenitas Pretest dan Posttest

\begin{tabular}{c|c|c|c}
\hline Kelas & $\begin{array}{c}\text { Levene } \\
\text { Statistic }\end{array}$ & Sig. & $\begin{array}{c}\text { Keteran } \\
\text { gan }\end{array}$ \\
\hline $\begin{array}{c}\text { Eksperim } \\
\text { en dan }\end{array}$ & Data Pretest & 0,15 & $\begin{array}{c}\text { Data } \\
\text { Homoge } \\
\text { Kontrol }\end{array}$ \\
\hline $\begin{array}{c}\text { Eksperim } \\
\text { en dan } \\
\text { Kontrol }\end{array}$ & $\begin{array}{c}\text { Data } \\
\text { Posttest }\end{array}$ & $\begin{array}{c}0,40 \\
3\end{array}$ & $\begin{array}{c}\text { Data } \\
\text { Homoge } \\
\mathrm{n}\end{array}$ \\
\hline
\end{tabular}

Berdasarkan tabel 7 maka diperoleh data hasil uji homogenitas data pretest menunjukkan hasil signifikansi 0,153 > 0,05 . Sedangkan hasil uji homogenitas data posttest menunjukkan hasil signifikansi $0,403>0,05$. Dapat disimpulkan bahwa data pretest dan posttest kelas eksperimen maupun kontrol memiliki varian yang sama (homogen).

\section{Uji Hipotesis}

Tabel 7. Hasil Uji Hipotesis Pretest dan Posttest

\begin{tabular}{c|c|c|c}
\hline Kelas & $\begin{array}{c}\text { Independe } \\
\text { nt Samples } \\
\text { Test }\end{array}$ & Sig. & $\begin{array}{c}\text { Keteranga } \\
\text { n }\end{array}$ \\
\hline Eksperim & Data Pretest & 0,48 & Ho \\
\hline
\end{tabular}

\begin{tabular}{c|c|c|c}
\hline $\begin{array}{c}\text { en dan } \\
\text { Kontrol }\end{array}$ & & 8 & $\begin{array}{c}\text { diterima } \\
\text { Ha ditolak }\end{array}$ \\
\hline $\begin{array}{c}\text { Eksperim } \\
\text { en dan } \\
\text { Kontrol }\end{array}$ & $\begin{array}{c}\text { Data } \\
\text { Posttest }\end{array}$ & $\begin{array}{c}0,00 \\
2\end{array}$ & $\begin{array}{c}\text { Ha } \\
\text { diterima } \\
\text { Ho ditolak }\end{array}$ \\
\hline
\end{tabular}

Berdasarkan tabel 7 dapat dilihat pada tabel data pretest dengan nilai Sig. $(0,488)>0,05$ maka Ho diterima dan Ha ditolak. Hal ini berarti bahwa tidak terdapat perbedaan yang signifikan antara pretest kemampuan pemahaman konsep siswa kelas eksperimen dan siswa kelas kontrol. Sedangkan data posttest diperoleh nilai Sig. $(0,002)<0,05$ maka Ha diterima dan Ho ditolak. Hal ini berarti terdapat perbedaan yang signifikan antara kemampuan pemahaman konsep siswa kelas eksperimen dan siswa kelas kontrol.

\section{Pembahasan}

Hasil penelitian menunjukkan bahwa kemampuan pemahaman konsep siswa kelas eksperimen bebeda dengan siswa kelas kontrol. Kelas eksperimen mendapatkan perlakuan penerapan model inkuriri terbimbing berbantuan media audio visual, sedangkan kelas kontrol mendapatkan perlakuan menggunakan model konvensional.

Model inkuiri terbimbing adalah proses pembelajaran dimana guru membimbing siswa untuk melakukan kegiatan penyelidikan guna menemukan sendiri atas jawaban yang dipermasalahkan. Pengetahuan yang diperoleh bukanlah rangkaian fakta hasil dari hafalan, melainkan hasil dari suatu proses dimana siswa menemukan sendiri jawabannya sehingga pembelajaran akan lebih bermakna. Hal ini sesuai dengan salah satu kelebihan model inkuiri terbimbing yang diungkapkan oleh Sugandi (dalam Rizkina, 2019) bahwa model inkuiri terbimbing berpusat pada siswa sehingga siswa ikut terlibat secara aktif dalam proses pembelajaran.

Hasil analisis deskriptif data kemampuan pemahaman konsep pada kelas eksperimen menggunakan model inkuiri 
terbimbing berbantuan media audio visual menunjukkan skor rata-rata adalah 86,16 dengan kategori tinggi dan pada kelas kontrol menggunakan model konvensional menunjukkan skor rata-rata adalah 76,79 dengan kategori sedang. Hal ini berarti skor rata-rata kelas eksperimen lebih tinggi daripada kelas kontrol. Skor rata-rata menggambarkan hasil yang diraih oleh sebagian besar siswa (Wahyuni, 2020). Hal tersebut didukung oleh penelitian Koten et al (2019) yang membuktikan bahwa model inkuiri terbimbing berpengaruh terhadap pemahaman konsep IPA siswa.

Hasil uji hipotesis posttest kelas eskperimen dan kontrol menggunakan uji independent sample t test diperoleh nilai sig $0,002<0,05$ maka Ha diterima dan Ho ditolak. Sedangkan thitung $=3,383>$ ttabel $=2,021$ dengan $\mathrm{df}=40$ pada taraf signifikasi 5\%. Maka dapat disimpulkan bahwa terdapat perbedaan yang signifikan antara kemampuan pemahaman konsep siswa kelas eksperimen dan siswa kelas kontrol. NRC (2011) mengungkapkan bahwa model inkuiri terbimbing dapat melatih dan mengembangkan kemampuan pemahaman konsep siswa. Hal ini sejalan dengan penelitian yang dilakukan oleh (Dewi \& Sudana, 2016) yang mebuktikan bahwa model pembelajaran inkuiri terbimbing berpengaruh terhadap pemahaman konsep IPA.

Model inkuiri terbimbing berbantuan media audio visual berpengaruh terhadap kemampuan pemahaman konsep siswa disebabkan karena berbagai faktor. Faktor pertama, model inkuiri terbimbing berbantuan media audio visual memiliki lima tahapan yang melibatkan siswa aktif secara langsung yang memiliki enam tahapan (Hosnan, 2014) yaitu: orientasi, merumuskan masalah, menentukan hipotesis, megumpulkan data, menguji hipotesis dan menarik kesimpulan. Keenam tahapan tersebut melibatkan siswa aktif dalam proses pembelajaran. Temuan tersebut didukung oleh pendapat Trianto (dalam Tariani et al., 2014) yang mengatakan bahwa pembelajaran inkuiri merupakan kegiatan belajar aktif yang menuntut siswa untuk menemukan dan mempelajari masalah sehingga dapat membentuk kesimpulan sendiri dengan percaya diri. Penelitian (Siahaan et al., 2021) juga membuktikan bahwa model inkuiri terbimbing dengan multi representatsi berpengaruh terhadap penguasaan konsep IPA.

Faktor kedua, dalam pelaksanaan model inkuiri terbimbing dibantu dengan media audio visual berupa video pembelajaran. Dengan menggunakan video saat pengamatan siswa dapat memahami konsep pembelajaran serta membuat pembelajaran lebih menyenangkan dan membuat siswa lebih tertarik akan proses pembelajaran. Media audio visual lebih baik daripada media audio dan media visual karena media audio visual meliputi kedua jenis media tersebut. Hal ini sesuai dengan penelitian Djamarah dan Zain (dalam Rosyid et al., 2019) yang menunjukkan bahwa media audio visual menunjukkan pengaruh yang cukup tinggi di atas 60\% sampai $80 \%$. Nugraha et al (dalam Magfirah et al., 2019) juga mengungkapkan, dengan memanfaatkan video sebagai media pembelajaran dapat memberikan dampak positif seperti pemahaman konsep siswa. Hal ini sejalan dengan penelitian (Yolanda et al., 2019) menunjukkan model pembelajaran inkuiri terbimbing berbantuan video kontekstual berpengaruh terhadap penguasaan konsep fisika siswa.

Merujuk pada hasil penelitian dan analisis di atas, menunjukkan bahwa penggunaan media audio visual dalam model pembelajaran terbimbing memberikan kontribusi yang positif. Selain positif, hasil penelitian juga berpengaruh terhadap kemampuan pemahaman konsep siswa pada kelas IV SDN 001 Air Tiris Kecamatan Kampar. Penggunaan media audio visual pada model inkuiri terbimbing memiliki hasil kemampuan pemahaman konsep siswa lebih tinggi dibandingkan dengan kelas kontrol yang hanya menggunakan model konvensional. Dapat 
Jurnal Edumaspul, 5 (2), Year 2021 - 350

(Hayatun Nupus, Molli Wahyuni, Lusi Marleni)

disimpulkan bahwa model inkuiri terbimbing berbantuan media audio visual berpengaruh terhadap kemampuan pemahaman konsep siswa.

\section{Simpulan}

Berdasarkan hasil penelitian dan pembahasan dapat disimpulkan bahwa ratarata kemampuan pemahaman konsep pada kelas eksperimen setelah perlakuan yang belajar melalui model inkuiri terbimbing berbantuan media audio visual berpengaruh sebesar 86,16 yang berkategori tinggi. Sedangkan di kelas kontrol setelah perlakuan yang belajar menggunakan model konvensional berpengaruh sebesar 76,79 yang berkategori sedang. Hal ini juga dibuktikan dengan pengujian hipotesis dengan taraf signifikansi 5\% diperoleh nilai sig (2-tailed) sebanyak 0,002 <0,05 yang menunjukkan bahwa kemampuan pemahaman konsep kedua kelas berbeda secara signifikan sehingga $\mathrm{H}_{\mathrm{a}}$ diterima dan $\mathrm{H}_{\mathrm{o}}$ ditolak. Jadi dapat disimpulkan bahwa model inkuiri terbimbing berbantuan media audio visual berpengaruh terhadap kemampuan pemahaman konsep siswa IV SDN 001 Air Tiris.

\section{Daftar Pustaka}

Abdillah, C., \& Anggara, D. S. (2021). Analisis Pemahaman Konsep Ipa Siswa Pada. Jurnal Cakrawala Pendas, 7(1), 52-61.

Ananda, R. (2017). Penggunaan Media Audio Visual untuk Meningkatkan Hasil Belajar Pendidikan Kewarganegaraan Siswa Kelas IV SD Negeri 016 Bangkinang Kota. Jurnal Basicedu, 1(1), 21-30. https://doi.org/10.31004/basicedu.vli1 .149

Arsyad, A. (2016). Media Pembelajaran (Edisi Revi). PT. Raja Grafindo Persada.

Budiasa, P., \& Ketut Gading, I. (2020). Model Pembelajaran Inkuiri Terbimbing Berbantuan Media
Gambar Terhadap Keaktifan dan Hasil Belajar IPA. Ejournal.Undiksha.Ac.Id, $8(2)$, 253-263. https://ejournal.undiksha.ac.id/index.p $\mathrm{hp} / \mathrm{JJPGSD} /$ article/view/26526

Chalilati. (2019). Penerapan Pendekatan Contextual Teaching And Learning (CTL) Untuk Meningkatkan Pemahaman Konsep Siswa Kelas IV Min 20 Aceh Besar.

Dewi, N. L. G. K. K., \& Sudana, D. N. (2016). Pengaruh Model Pembelajaran Inkuiri Terbimbing Terhadap Pemahaman Konsep IPA Dengan Mengontrol Minat Belajar Pada Siswa Kelas V SD. Jurnal Pendidikan Dan Pengajaran, $49(1)$, https://doi.org/10.23887/jppundiksha.v 49i1.9008

Hosnan, M. (2014). Pendekatan saintifik dan kontekstual dalam pembelajaran abad 21: Kunci sukses implementasi kurikulum 2013.

Koten, V. S., Suharti, S., \& Sutopo, S. (2019). Pemahaman Konsep Siswa Kelas IV melalui Pembelajaran Inkuiri Terbimbing tentang Materi Sifat-Sifat Cahaya. Jurnal Pendidikan: Teori ..., 1145-1148.

http://journal.um.ac.id/index.php/jptpp /article/view/12692

Magfirah, A., Hidayat, A., \& Mahanal, S. (2019). Penggunaan Media Audiovisual pada Model Inkuiri Terbimbing terhadap Keterampilan Proses Sains dan Penguasaan Konsep IPA. Jurnal Pendidikan, 4(1), 96-103.

Ningsih, D. S. (2019). Meningkatkan Pemahaman Konsep IPA Melalui Metode Demonstrasi Di Kelas VB SDN 61/X Talang Babat. Jurnal Gentala Pendidikan Dasar, 4(1), 22 40.

https://doi.org/10.22437/gentala.v4i1.6 849

NRC. (2011). Inkuiri dan Standar-Standar Pendidikan Sains Nasional. National Academy Press.

Permendikbud. (2013). Peraturan Menteri dan Kebudayaan RI No. 67 tentang 
KD dan Struktur Kurikulum SD/MI. Kementerian Pendidikan dan Kebudayaan.

Rizkina, M. (2019). Penerapan Model Inkuiri Terbimbing (Guided Inquiry) Disertai Media Audio Visual Pada Materi Bakteri Untuk Meningkatkan Kemampuan Berpikir Kritis Siswa Di MAN 3 Aceh Besar.

Rosyid, M. Z., Sa'diyah, H., \& Septiana, N. (2019). Ragam Media Pembelajaran. CV. Literasi Nusantara Abadi.

Samatowa, U. (2011). Pembelajaran IPA di sekolah dasar. PT Indeks.

Siahaan, K. W. A., Lumbangaol, S. T. P., Marbun, J., \& Nainggolan, A. D. (2021). Pengaruh Model Pembelajaran Inkuiri Terbimbing dengan Multi Representasi terhadap Keterampilan Proses Sains dan Penguasaan Konsep IPA. Jurnal Basicedu, 5(1), 195-205.

Siregar, N. (2019). Peningkatan Kemampuan Pemahaman Konsep IPA Siswa Dan Pengelolaan Pembelajaran Guru Dengan Menerapkan Model Pembelajaran Berbasis Masalah. EKSAKTA: Jurnal Penelitian Dan Pembelajaran MIPA, 4(1), 60. https://doi.org/10.31604/eksakta.v4i1. 60-65

Sugiyono. (2019). Metode Penelitian Kuantitatif Kualitatif dan $R$ \& $D$. Alfabeta.
Tariani, K., Syahruddin, H., \& Desak, P. P. (2014). Pengaruh Model Pembelajaran Inkuiri Terbimbing Terhadap Pemahaman Konsep IPA Siswa Kelas V. E-Journal MIMBAR PGSD Universitas Pendidikan Ganesha, 2(1), $1-10$.

Wahyuni, M. (2020). Statistik Deskriptif untuk Penelitian Olah Data Manual dan SPSS Versi 25. Bintang Pustaka Madani.

Yolanda, S. E., Gunawan, \& Sutrio. (2019). Pengaruh Model Pembelajaran Inkuiri Terbimbing Berbantuan Media Video Kontekstual Terhadap Penguasaan Konsep Fisika Peserta Didik. 341347.

Zani, P. (2018). Pengaruh Metode Scramble Terhadap Keterampilan Membaca Pemahaman Pada Mata Pelajaran Bahasa Indonesia Siswa Sekolah Dasar. Universitas Pahlawan Tuanku Tambusai.

\section{Profil Penulis}

Hayatun Nupus lahir di Pulau Sarak, 10 Mei 1999. Peneliti merupakan anak pertama dari dua bersaudara. Peneliti kuliah di Universitas Pahlawan Tuanku Tambusai Bangkinang Riau dengan jurusan S1 Pendidikan Guru Sekolah Dasar dan lulus pada tahun 2021. 